\title{
ASPEK-ASPEK YANG BERPENGARUH DALAM \\ PENGGUNAAN E-FILING ADMNISTRASI PERPAJAKAN DAN DAMPAKNYA TERHADAP KEPUASAN WAJIB PAJAK
}

\author{
Amilin dan Ana Nurjanah \\ Fakultas Ekonomi dan Bisnis UIN Syarif Hidayatullah Jakarta. \\ Email: msmagister1@gmail.com
}

\begin{abstract}
The purposes of this study to analyze the influence of easy of use, usefulness, security and privacy to taxpayer's satisfaction in e-filing using. The population of this research is Corporate Taxpayers. Primary data used in this study collected by the questionnaire in Jakarta Area. Convenience sampling method used in this study.There are any 86 from 88 questionnaires are feasible to analyzed. The multiple regression analysis used to test the hyphotesis. The result of this study showed that easy of use, usefulness, security and privacy positively influence and significant to taxpayer's satisfaction.
\end{abstract}

Keywords: e-filing, easy of use, usefulness, security and privacy, taxpayer's satisfaction.

\begin{abstract}
Abstrak: Tujuan penelitian ini adalah untuk menguji pengaruh kemudahan dalam penggunaan, kemanfaatan, dan keamanan serta kerahasiaan fungsi fasilitas elektronik perpajakan terhadap kepuasan Wajib Pajak dalam menggunakan fasilitas $e$-Filing. Populasi penelitian ini adalah Wajib Pajak Badan. Data primer dikumpulkan melalui penyebaran kuesioner di wilayah Jakarta. Pemilihan sampel penelitian menggunakan convenience sampling. Jumlah kuesioner yang berhasil dikumpulkan sebanyak 88 buah dan yang memenuhi syarat untuk diolah sebanyak 86 buah. Metode analisis data untuk menguji hipotesis menggunakan metode analisis regresi berganda. Hasil penelitian ini menunjukan bahwa kemudahan penggunaan, kemanfaatan, keamanan dan kerahasiaan berpengaruh secara positif dan signifikan terhadap kepuasan Wajib Pajak.
\end{abstract}

Kata kunci: e-filing, kemudahan penggunaan, kemanfaatan, keamanan dan kerahasiaan, kepuasan wajib pajak.

\section{PENDAHULUAN}

Pajak merupakan salah satu sumber penerimaan negara terbesar. Penerimaan ini sangat berperan dalam kesejahteraan masyarakat Indonesia (Noviandini, 2012: 2). Oleh karena itu, pemerintah selalu berusaha untuk terus-menerus berupaya meningkatkan pendapatan negara dari sektor pajak. Dalam administrasi perpajakan ini, banyak akuntan dalam pekerjaannya berhubungan dengan masalah administrasi perpajakan. Untuk melihat seberapa besar kontribusi pajak terhadap penerimaan negara, berikut ini disajikan data penerimaan negara dari sektor pajak. 
Tabel 1. Realisasi Penerimaan Negara Periode 2007 - 2012 (Milyaran Rupiah)

\begin{tabular}{lrrrrrr}
\hline Sumber Penerimaan & \multicolumn{1}{c}{$2007^{1)}$} & \multicolumn{1}{c}{$2008^{1)}$} & \multicolumn{1}{c}{$2009^{1)}$} & \multicolumn{1}{c}{$2010^{1)}$} & \multicolumn{1}{c}{$2011^{2)}$} & \multicolumn{1}{c}{$2012^{1)}$} \\
\hline Penerimaan Perpajakan & 490,988 & 658,701 & 619,922 & 723,307 & 878,685 & $1,019,333$ \\
Pajak Dalam Negeri & 470,052 & 622,359 & 601,252 & 694,392 & 831,745 & 976,900 \\
Pajak penghasilan & 238,431 & 327,498 & 317,615 & 357,045 & 431,977 & 512,835 \\
Pajak Pertambahan Nilai & 154,527 & 209,647 & 193,067 & 230,605 & 298,441 & 350,343 \\
Pajak Bumi dan Bangunan & 23,724 & 25,354 & 24,270 & 28,581 & 29,058 & 35,647 \\
Bea Perolehan Hak atas & 5,953 & 5,573 & 6,465 & 8,026 & - & - \\
Tanah dan Bangunan & & & & & & \\
Cukai & 44,679 & 51,252 & 56,719 & 66,166 & 68,075 & 72,443 \\
Pajak Lainnya & 2,738 & 3,035 & 3,116 & 3,969 & 4,194 & 5,632 \\
Pajak Perdagangan Internional & 20,936 & 36,342 & 18,670 & 28,915 & 46,940 & 42,433 \\
Bea Masuk & 16,699 & 22,764 & 18,105 & 20,017 & 21,501 & 23,534 \\
Pajak Ekspor & 4,237 & 13,578 & 565 & 8,898 & 25,439 & 18,899 \\
\hline
\end{tabular}

Sumber: http://www.bps.go.id/tab_sub/view.php?tabel=1\&daftar=1\&id_subyek=13

Dari tabel tersebut dapat dilihat bahwa penerimaan negara yang bersumber dari sektor pajak hampir setiap tahunnya mengalami peningkatan. Direktorat Jenderal Pajak (DJP) terus berusaha untuk memperbaharui sistem administrasi perpajakan dalam meningkatkan penerimaannya. Sistem Informasi Pajak yang terintegrasi dengan menggunakan Intranet akan lebih memudahkan konfirmasi antar unit strategi setingkat Kantor Pelayanan Pajak (KPP) dan juga memudahkan wajib pajak yang akan melakukan restitusi, dalam hal penerimaan jawaban konfirmasi (Devano dan Kurnia, 2006:27-28).

Hadirnya e-Filing yang mudah digunakan, memberikan manfaat, dan dapat meningkatkan keamanan dan kerahasiaan merupakan kewajiban Direktorat Jenderal Pajak dalam meningkatkan kualitas pelayanan sehingga diharapkan dapat menimbulkan rasa puas bagi para penggunanya (Prianggono dan Manuputty, 2011:3). Sehubungan dengan hal tersebut, Direktorat Jenderal Pajak telah mengeluarkan keputusan Direktorat Jenderal Pajak Nomor KEP-88/PJ/2004 tanggal 14 Mei 2004 (BN No. 7069 hal. 4B) tentang Penyampaian Surat Secara Elektronik.

Berdasarkan uraian di atas, peneliti tertarik untuk melakukan penelitian hal-hal yang diduga dapat mempengaruhi kepuasan Wajib Pajak dalam menggunakan e-Filing khususnya dalam aspek kemudahan dalam penggunaan, kemanfaatan, dan keamanan serta kerahasiaan fungsi fasilitas elektronik perpajakan.

Penelitian ini melengkapi penelitian sebelumnya yang dilakukan oleh Noviandini (2012) dengan menambahkan variabel independen keamanan dan kerahasiaan (security and privacy). Selain itu, penelitian ini menempatkan variabel kepuasan wajib pajak sebagai variabel dependen dalam model penelitiannya. Penempatan posisi variabel kepuasan wajib pajak sebagai variabel dependen dalam penelitian ini dengan alasan karena faktor kepuasan merupakan variabel yang dipengaruhi dalam hubungan kausalitas. Dengan kata lain, kepuasan wajib pajak merupakan hal yang semestinya dapat dirasakan oleh wajib pajak atas penggunaan sistem e-Filing. Hal lain yang membedakan antara penelitian ini dengan penelitian sebelumnya yaitu dalam hal lokasi dilakukannya penelitian. Penelitian ini dilakukan Jakarta pada tahun 2014, sedangkan penelitian Noviandini dilakukan di Yogyakarta dan telah dipublikasikan dalam jurnal ilmiah pada tahun 2012. Penelitian ini sangat perlu dilakukan mengingat kontribusinya begitu penting untuk mendorong kebijakan Pemerintah dalam upaya meningkatkan pendapatan negara dari sektor pajak. Hasil penelitian ini diharapkan dapat dijadikan sebagai bahan 
pertimbangan bagi Kantor Pelayanan Pajak maupun Direktorat Jenderal Pajak dalam upaya mengevaluasi kebijakan sekaligus memberikan masukan untuk peningkatan pelayanan kepada wajib pajak dengan sistem e-Filing khususnya dalam aspek kemudahan dalam penggunaan, kemanfaatan, serta keamanan dan kerahasiaan data wajib pajak. Jika wajib pajak merasa puas dengan kualitas pelayanan yang diberikan diharapkan dapat meningkatkan kesadaran wajib pajak dalam memenuhi kewajiban perpajakannya.

Berdasarkan latar belakang di atas, maka masalah penelitian ini dapat dirumuskan sebagai berikut: “Apakah aspek kemudahan dalam penggunaan, kemanfaatan, serta keamanan dan kerahasiaan berpengaruh terhadap kepuasan Wajib Pajak dalam penggunaan $e$-Filing?”

Tujuan penelitian ini adalah untuk memperoleh bukti empiris tentang pengaruh aspek kemudahan dalam penggunaan, kemanfaatan, serta keamanan dan kerahasiaan terhadap kepuasan Wajib Pajak dalam penggunaan e-Filing.

Technology Accaptance Model Theory. Teori Technology Acceptance Model (TAM) dikembangkan oleh Davis F.D (1986). Teori ini menjelaskan tentang perilaku penggunaan komputer yang dikembangkan dari Theory of Reasoned Action (TRA) yang dibuat khusus untuk pemodelan penerimaan pengguna dalam sistem informasi (Laihad, 2013:3). Tujuan dari teori TAM adalah untuk memberi penjelasan secara umum mengenai hal-hal yang menentukan penerimaan keberadaan teknologi (Pratiwi, 2012). Tujuan lainnya adalah dijadikan sebagai dasar untuk memahami pengaruh faktor-faktor eksternal yang ada dalam keyakinan internal (internal beliefs) dan tingkah laku (attitude) seseorang (Devi dan Suartana, 2014).

Hubungan Kemudahan Penggunaan dengan Kepuasan Wajib Pajak dalam Penggunaan $\boldsymbol{e}$-Filing. Penelitian yang dilakukan oleh Irmadhani dan Nugroho (2011) pada industri perbankan mengenai persepsi nasabah tentang kemudahan penggunaan fasilitas online banking, hasilnya menunjukkan bukti empiris bahwa persepsi nasabah tentang kemudahan penggunaan fasilitas online banking dapat berpengaruh positif terhadap praktik penggunaan online banking. Namun demikian, pengaruhnya ini tidak signifikan. Penelitian lainnya yang dilakukan oleh Pratiwi (2012) menunjukkan bukti empiris bahwa persepsi kemudahan penggunaan fasilitas mobile banking tidak berpengaruh secara signifikan terhadap niat nasabah untuk menggunakan fasilitas mobile banking. Hasil ini diduga karena nasabah tidak perlu effort yang cukup keras dalam menggunakan fasilitas teknologi layanan mobile banking.

Sedangkan penelitian yang dilakukan oleh Noviandini (2012) memperoleh bukti empiris bahwa persepsi kemudahan wajib pajak dalam menggunakan fasilitas e-filing berpengaruh positif dan signifikan terhadap penggunaan fasilitias $e$-filing. Semakin tinggi tingkat persepsi kemudahan penggunaan, maka wajib pajak akan semakin sering pula menggunakan e-Filing. Atas temuan ini, dapat dijelaskan lebih lanjut sebagai berikut. Persepsi kemudahan penggunaan akan mengurangi usaha Wajib Pajak dalam kerumitan mengisi SPT melalui $e$-Filing. Jika seseorang merasa bahwa sistem yang ada mudah digunakan, maka ia akan menggunakannya, sehingga kemudahan penggunaan e-Filing akan mempengaruhi sikap Wajib Pajak dalam menggunakan $e$-Filing. Dengan sistem yang lebih dikenal, lebih mudah dioperasikan dan lebih mudah digunakan oleh penggunanya akan menciptakan rasa kepuasan Wajib Pajak yang muncul akibat kemudahan penggunaan e-Filing. Berdasarkan temuan tersebut, maka dapat dirumuskan hipotesis sebagai berikut: 
$\mathrm{H}_{\mathrm{a} 1}$ : Persepsi kemudahan penggunaan $e$-Filing berpengaruh secara positif dan signifikan terhadap kepuasan Wajib Pajak.

Hubungan Kemanfaatan dengan Kepuasan Wajib Pajak dalam Penggunaan E-Filing. Penelitian yang dilakukan oleh Pratiwi (2012) menunjukkan bukti empiris bahwa persepsi tentang manfaat penggunaan fasilitas mobile banking berpengaruh terhadap layanan penggunaan fasilitas mobile banking. Responden mempersepsikan bahwa mobile banking memberikan kemanfaatan yang tinggi terutama untuk meningkatkan kinerja, dapat mempercepat penyelesaian pekerjaan dan meningkatkan efisiensi waktu kerja.

Penelitian lainnya yang dilakukan oleh Irmadhani dan Nugroho (2011) menunjukkan bukti empiris bahwa persepsi kebermanfaatan dapat berpengaruh secara positif dan signifikan terhadap penggunaan fasilitas Online Banking. Indikator yang digunakan untuk mengukur persepsi kebermanfaatan adalah penggunaan online banking yang mampu meningkatkan kinerja, menambah tingkat produktifitas dan efektifitas kerja, sehingga online banking dapat memberikan manfaat dalam melaksanakan tugas atau pekerjaan nasabah.

Penelitian selanjutnya yang dilakukan oleh Noviandini (2012) menunjukkan bukti empiris bahwa persepsi kebermanfaatan berpengaruh positif dan signifikan terhadap penggunaan $e$-Filing. Dengan demikian, persepsi atas kebermanfaatan mempengaruhi tingkat penggunaan e-Filing. Semakin tinggi persepsi seseorang mengenai kebermanfaatannya $e$-Filimg maka semakin banyak yang menggunakan fasilitas $e$-Filing. Dengan bermanfaatnya $e$-Filing maka akan diperoleh kepuasan yang dirasakan oleh Wajib Pajak, semakin bermanfaat suatu sistem maka akan semakin tinggi tingkat kepuasan Wajib Pajak dalam menggunakan e-Filing. Dengan demikian, maka dapat dirumuskan hipotesis sebagai berikut:

$\mathrm{H}_{\mathrm{a} 2}$ : Persepsi kemanfaatan penggunaan $e$-Filing berpengaruh secara positif dan signifikan terhadap kepuasan Wajib Pajak.

Hubungan Keamanan dan Kerahasiaan dengan Kepuasan Wajib Pajak dalam Penggunaan E-filing. Hasil penelitian yang dilakukan oleh Desmayanti (2012) menunjukkan bukti empiris bahwa keamanan dan kerahasiaan berpengaruh secara positif dan signifikan terhadap intensitas perilaku para pengguna $e$-Filing. Semakin tinggi tingkat keamanan dan kerahasiaan, maka Wajib Pajak semakin sering dalam menggunakan $e$ Filing. Dengan keamanan dan kerahasiaan sistem yang diberikan oleh aparatur pajak maka Wajib Pajak akan merasa puas. Hal ini disebebkan karena keamanan dan kerahasiaan merupakan hal yang penting dan harus diperhatikan sehingga Wajib Pajak akan senantiasa selalu menggunakan e-Filing. Berdasarkan atas temuan ini maka dapat dirumuskan hipotesis sebagai berikut:

$\mathrm{H}_{\mathrm{a} 3}$ : Keamanan dan kerahasiaan penggunaan e-Filing berpengaruh secara positif dan signifikan terhadap kepuasan Wajib Pajak.

\section{METODE}

Populasi dan Metode Pemilihan Sampel. Jenis penelitian ini merupakan penelitian kausalitas. Populasi dalam penelitian ini adalah Wajib Pajak Badan yang berada di area Jakarta. Responden yang berpartisipasi dalam penelitian ini adalah pegawai perusahaan 
yang mengelola masalah perpajakan. Pengambilan sampel dilakukan dengan metode convenience sampling. Pengumpulan data lapangan menggunakan kuesioner dengan teknik personally administered questionnaires. Dalam teknik ini, kuisioner disampaikan kepada responden dan dikumpulkan langsung oleh peneliti (Indriantoro dan Supomo, 2004: 154).

Operasionalisasi Variabel Penelitian. Variabel Independen terdiri dari variabel: Persepsi tentang Kemudahan Penggunaan $\left(\mathrm{X}_{1}\right)$, Kemanfaatan $\left(\mathrm{X}_{2}\right)$, Keamanan dan Kerahasiaan $\left(\mathrm{X}_{3}\right)$. Sedangkan Variabel Dependennya adalah Kepuasan Wajib Pajak (Y).

Variabel Kemudahan Penggunaan ( $\left.\mathbf{X}_{\mathbf{1}}\right)$. Persepsi tentang kemudahan penggunaan merupakan tingkat keyakinan seseorang dalam menggunakan sistem tertentu dengan tidak diperlukan usaha yang keras (Davis, 1989). Variabel ini diukur dengan menggunakan 6 buah item pertanyaan dengan skala interval: sangat tidak setuju (1), tidak setuju (2), netral (3), setuju (4) dan sangat setuju (5).

Variabel Kemanfaatan $\left(\mathbf{X}_{2}\right)$. Persepsi kemanfaatan didefinisikan sebagai tingkatan sejauh mana seseorang yakin bahwa menggunakan sebuah sistem akan meningkatkan kinerjanya (Davis, 1989). Diukur dengan menggunakan 9 buah item pertanyaan dengan skala interval: sangat tidak setuju (1), tidak setuju (2), netral (3), setuju (4) dan sangat setuju (5).

Variabel Keamanan dan Kerahasiaan ( $\left.\mathbf{X}_{3}\right)$. Keamanan informasi digunakan untuk mendeskripsikan perlindungan baik peralatan komputer dan non komputer, fasilitas, data dan informasi dari penyalahgunaan pihak-pihak yang tidak berwenang. Salah satu tujuan dari keamanan informasi ini adalah terjaga kerahasiaan untuk melindungi data dan informasi dari pengungkapan kepada orang-orang yang tidak berwenang (Raymond dan George, 2000:270). Variabel ini terdiri dari 7 pertanyaan dan diukur menggunakan skala interval: sangat tidak setuju (1), tidak setuju (2), netral (3), setuju (4) dan sangat setuju (5).

Variabel Kepuasan Wajib Pajak. Kepuasan adalah perasaan senang atau kecewa seseorang yang muncul setelah membandingkan antara persepsi atau kesannya terhadap kinerja atau hasil suatu produk dan harapan-harapannya (Kotler, 2000:42). Dalam penelitian ini konteksnya adalah kepuasan wajib pajak. Variabel ini tediri dari 8 pertanyaan yang diukur dengan menggunakan skala interval: sangat tidak setuju (1), tidak setuju (2), netral (3), setuju (4) dan sangat setuju (5).

Metode Analisis Data. Metode analisis data menggunakan uji statistik deskriptif, uji kualitas data, uji asumsi klasik. Pengujian statistik deskriptif terdiri dari: jumlah data (sum), data maksimum, data minimum, data rata-rata (mean), dan data deviasi standar. Pengujian kualitas data terdiri dari uji validitas dan reliabilitas data. Uji validitas dilakukan dengan membandingkan nilai $r_{\text {hitung }}$ dengan $r_{\text {tabel }}$. Jika $r_{\text {hitung }}$ lebih besar dari $r_{\text {tabel }}$ maka butir pertanyaan tersebut adalah valid, tetapi jika $r_{\text {hitung }}$ lebih kecil dari pada $\mathrm{r}_{\text {tabel }}$ maka butir pertanyaan tersebut tidak valid (Ghozali, 2011:53). Uji realibilitas data menggunakan metode Cronbach's Alpha. Nilai alpha bervariasi dari 0-1, suatu pertanyaan dapat dikategorikan reliabel jika nilai alpha lebih besar dari 0,70 (Ghozali, 2011: 48). 
Uji asumsi klasik terdiri dari: uji normalitas, uji multikolonieritas, dan uji heteroskedastisitas. Uji normalitas data menggunakan Normal Probability Plot. Pengujian multikolinearitas dapat dideteksi melalui besaran VIF (Variance Inflation Factor) dan tolerance. Model regresi dapat dikatakan bebas dari problem multikolonieritas jika nilai VIF $<10$ dan nilai tolerance $>$ 0,10 (Ghozali, 2011:105-106).

Uji heteroskedastisitas menggunakan grafik Plot. Jika grafik plot menunjukkan suatu pola titik yang bergelombang atau melebar kemudian menyempit, maka dapat disimpulkan bahwa telah terjadi heteroskedastisitas. Namun, jika tidak ada pola yang jelas, serat titiktitik menyebar di atas dan di bawah angka 0 pada sumbu $Y$, maka tidak terjadi heteroskedastisitas (Ghozali, 2011:139). Uji hipotesis dalam penelitian ini menggunakan analisis regresi berganda.

Model Penelitian. Model analisis penelitian ini menggunakan model persamaan matematis melalui uji regresi berganda yang dirumuskan sebagai berikut:

$$
\mathbf{Y}=\mathrm{a}+\mathrm{b}_{1} \mathrm{X}_{1}+\mathrm{b}_{2} \mathrm{X}_{2}+\mathrm{b}_{3} \mathrm{X}_{3}+\mathrm{e}_{\mathrm{i}}
$$

Dimana: $\mathrm{Y}=$ Variabel Kepuasan Wajib Pajak; $\mathrm{a}=$ Konstanta; $\mathrm{b}_{1} \ldots . . \mathrm{b}_{2}=$ Koefisien regresi terhadap dugaan; $\mathrm{X}_{1}=$ Variabel Kemudahan Penggunaan; $\mathrm{X}_{2}=$ Variabel Kemanfaatan; $\mathrm{X}_{3}=$ Variabel Keamanan Dan Kerahasiaan; $\mathrm{e}_{1}=$ error term

Keputusan untuk menentukan apakah hasil pengujian hipotesis dapat didukung atau tidak dapat ditentukan berdasarkan nilai signifikasi. Jika nilai signifikansi lebih kecil dari0,05 (untuk tingkat keyakinan 95\%), maka variabel independen secara secara berpengaruh terhadap variabel dependen (Ghozali, 2011: 177).

\section{HASIL DAN PEMBAHASAN}

Tingkat Pengembalian Kuesioner. Berikut ini disajikan data tentang tingkat pengembalian kuesioner.

Tabel 2. Tingkat Pengembalian Kuesioner

\begin{tabular}{clcc}
\hline No & \multicolumn{1}{c}{ Keterangan } & $\begin{array}{c}\text { Jumlah } \\
\text { Responden }\end{array}$ & $\begin{array}{c}\text { Persentase } \\
(\%)\end{array}$ \\
\hline 1 & Jumlah kuesioner yang disebar & 88 & $100 \%$ \\
2 & Jumlah kuesioner yang tidak kembali & 0 & $0 \%$ \\
3 & Jumlah kuesioner yang tidak dapat diolah & 2 & $2 \%$ \\
4 & Kuesioner yang dapat diolah & 86 & $98 \%$ \\
\hline
\end{tabular}

Sumber: Data primer yang diolah

Dari 88 kuesioner yang disebarkan, 100\% kuesioner yang kembali. Dari kuesioner yang kembali, ada 2 kuesioner yang tidak dapat diolah, sehingga ada 86 kuesioner yang dapat diolah. Kuesioner yang tidak dapat diolah disebabkan karena jawaban atas pertanyaanpertanyaan yang ada dalam kuesioner tidak terisi dengan penuh serta tidak mencantumkan identitas resonden.

Profil Responden. Berikut ini disajikan data mengenai profil responden berdasarkan pendidikan terakhir yang disajikan dalam bentuk grafik. 


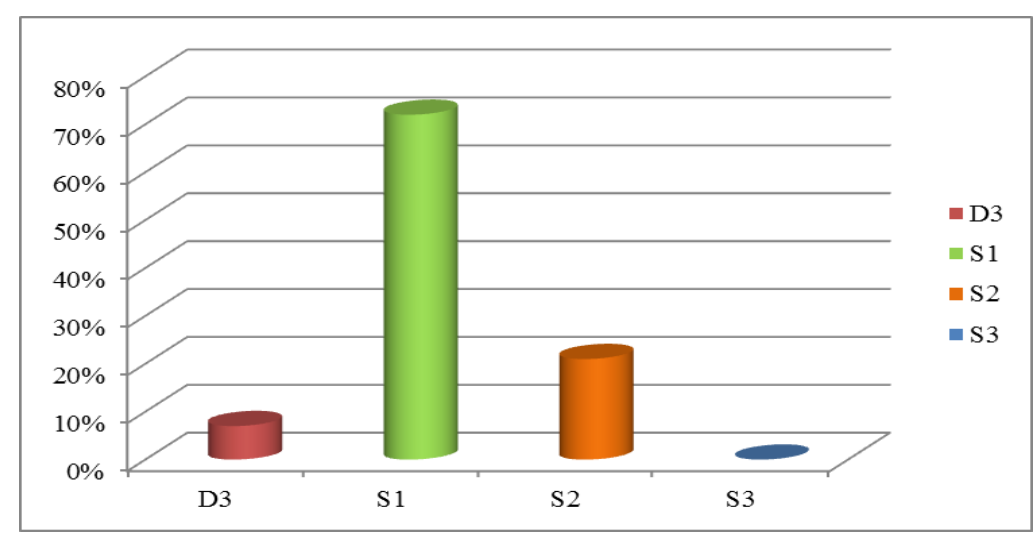

Gambar 1. Karakteristik Responden Berdasarkan Pendidikan Terakhir Sumber: data primer yang diolah

Berdasarkan grafik di atas dapat diketahui bahwa profil responden yang berpendidikan terakhir D3 berjumlah 6 responden (7\%), S1 berjumlah 62 responden (72\%), S2 berjumlah 18 responden (21\%), sedangkan S3 tidak ada.

Hasil Uji Statistik Deskriptif. Berikut ini disajikan data hasil uji statistik deskriptif.

Tabel 3. Hasil Uji Statistik Deskriptif Descriptive Statistics

\begin{tabular}{lcrrrr}
\hline & N & Minimum & Maximum & Mean & $\begin{array}{c}\text { Std. } \\
\text { Deviation }\end{array}$ \\
\hline Kemudahan Penggunaan & 86 & 3.00 & 5.00 & 4.0429 & .51666 \\
Kemanfaatan & 86 & 3.00 & 5.00 & 4.1020 & .47563 \\
Keamanan dan Kerahasiaan & 86 & 3.00 & 5.00 & 4.0219 & .53082 \\
Kepuasan Wajib Pajak & 86 & 3.00 & 5.00 & 4.1056 & .45195 \\
Valid N (listwise) & 86 & & & & \\
\hline
\end{tabular}

Sumber: data primer yang diolah

Berdasarkan tabel di atas dapat dideskripsikan bahwa jumlah responden sebanyak 86 orang. Variabel kemudahan penggunaan memiliki nilai minimum 3, nilai maksimum 5, nilai mean 4,0429, dengan standar deviasi 0,51666. Variabel kemanfaatan memiliki nilai minimum 3, nilai maksimum 5, nilai mean 4,1020, dengan standar deviasi 0,47563. Variabel keamanan dan kerahasiaan memiliki nilai minimum 3, nilai maksimum 5, nilai mean 4,1056 dengan standar deviasi 0,53082. Sedangkan pada variabel Kepuasan Wajib Pajak memiliki nilai minimum 3, nilai maksimum 5, nilai mean 4,1056 dengan standar deviasi 0,4195.

Hasil Uji Kualitas Data. Hasil Uji Validitas. Berikut ini disajikan hasil uji validitas data pada variabel kemudahan penggunaan.

Tabel 4. Hasil Uji Validitas Variabel Kemudahan Penggunaan

\begin{tabular}{cccc}
\hline Pertanyaan & Nilai rhitung & Nilai rabel & Kriteria \\
\hline KP1 & 0,441 & 0,213 & Valid \\
KP2 & 0,584 & 0,213 & Valid \\
\hline
\end{tabular}




\begin{tabular}{cccc}
\hline Pertanyaan & Nilai $r_{\text {hitung }}$ & Nilai $r_{\text {tabel }}$ & Kriteria \\
\hline KP3 & 0,762 & 0,213 & Valid \\
KP4 & 0,535 & 0,213 & Valid \\
KP5 & 0,607 & 0,213 & Valid \\
KP6 & 0,762 & 0,213 & Valid
\end{tabular}

Sumber: data primer yang diolah

Dari tabel diatas dapat diketahui bahwa semua butir pertanyaan pada variabel kemudahan penggunaan dinyatakan valid ( $r_{\text {hitung }}>\mathrm{r}_{\text {tabel}}$ ). Selanjutnya, berikut ini disajikan hasil uji validitas data untuk variabel Kemanfaatan.

Tabel 5. Hasil Uji Validitas Variabel Kemanfaatan

\begin{tabular}{cccc}
\hline Pertanyaan & Nilai rhitung $_{\text {K }}$ & Nilai rtabel $_{\text {}}$ & Kriteria \\
\hline KM1 & 0,628 & 0,213 & Valid \\
KM2 & 0,748 & 0,213 & Valid \\
KM3 & 0,604 & 0,213 & Valid \\
KM4 & 0,431 & 0,213 & Valid \\
KM5 & 0,426 & 0,213 & Valid \\
KM6 & 0,569 & 0,213 & Valid \\
KM7 & 0,599 & 0,213 & Valid \\
KM8 & 0,722 & 0,213 & Valid \\
KM9 & 0,636 & 0,213 & Valid \\
\hline
\end{tabular}

Sumber: data primer yang diolah

Variabel kemanfaatan terdiri atas 9 butir pernyataan, dari ke - 9 butir pernyataan semua butir pertanyaan dinyatakan valid ( $\mathrm{r}_{\text {hitung }}>\mathrm{r}_{\text {tabel}}$ ). Berikutnya, tabel di bawah ini menunjukkan hasil uji validitas dari variabel keamanan dan kerahasiaan.

Tabel 6. Hasil Uji Validitas Variabel Keamanan dan Kerahasiaan

\begin{tabular}{cccc}
\hline Pertanyaan & Nilai $\mathrm{r}_{\text {hitung }}$ & Nilai $\mathrm{r}_{\text {tabel }}$ & Kriteria \\
\hline KK1 & 0,515 & 0,213 & Valid \\
KK2 & 0,858 & 0,213 & Valid \\
KK3 & 0,526 & 0,213 & Valid \\
KK4 & 0,707 & 0,213 & Valid \\
KK5 & 0,653 & 0,213 & Valid \\
KK6 & 0,796 & 0,213 & Valid \\
KK7 & 0,445 & 0,213 & Valid \\
\hline
\end{tabular}

Sumber: data primer yang diolah

Variabel keamanan dan kerahasiaan terdiri atas 7 butir pernyataan, dari ke - 7 butir pernyataan semua butir pertanyaan dinyatakan valid ( $\mathrm{r}_{\text {hitung }}>\mathrm{r}_{\text {tabel}}$ ). Selanjutnya, tabel di bawah ini menunjukkan hasil uji validitas pada variabel kepuasan Wajib Pajak.

Tabel 7. Hasil Uji Validitas Variabel Kepuasan Wajib Pajak

\begin{tabular}{cccc}
\hline Pertanyaan & Nilai $\mathrm{r}_{\text {hitung }}$ & Nilai $\mathrm{r}_{\text {tabel }}$ & Kriteria \\
\hline KWP1 & 0,455 & 0,213 & Valid \\
KWP2 & 0,553 & 0,213 & Valid \\
KWP3 & 0,488 & 0,213 & Valid \\
\hline
\end{tabular}




\begin{tabular}{cccc}
\hline Pertanyaan & Nilai r $_{\text {hitung }}$ & Nilai $\mathrm{r}_{\text {tabel }}$ & Kriteria \\
\hline KWP4 & 0,541 & 0,213 & Valid \\
KWP5 & 0,614 & 0,213 & Valid \\
KWP6 & 0,437 & 0,213 & Valid \\
KWP7 & 0,520 & 0,213 & Valid \\
KWP8 & 0,596 & 0,213 & Valid \\
\hline
\end{tabular}

Sumber: data primer yang diolah

Variabel kepuasan Wajib Pajak terdiri atas 8 butir pernyataan, dari ke - 8 butir pernyataan semua butir pertanyaan dinyatakan valid ( $\mathrm{r}_{\text {hitung }}>\mathrm{r}_{\text {tabel }}$ ). Hasil Uji Reliabilitas Data. Berikut ini disajikan hasil uji reliabilitas data.

Tabel 8. Hasil Uji Reliabilitas

\begin{tabular}{lccc}
\hline \multicolumn{1}{c}{ Variabel } & Cronbach's Alpha & N of Items & Keterangan \\
\hline Kemudahan Penggunaan & 0,832 & 6 & Reliabel \\
Kemanfaatan & 0,864 & 9 & Reliabel \\
Keamanan dan Kerahasiaan & 0,867 & 7 & Reliabel \\
Kepuasan Wajib Pajak & 0,811 & 8 & Reliabel \\
\hline
\end{tabular}

Sumber: Data primer yang diolah

Tabel di atas menunjukkan nilai cronbach's alpha pada variabel kemudahan penggunaan sebesar 0,832, variabel kemanfaatan sebesar 0,864, variabel keamanan dan kerahasiaan sebesar 0,867 dan variabel kepuasan Wajib Pajak sebesar 0,811. Sehingga dapat disimpulkan bahwa pernyataan dalam kuesioner semua variabel ini reliabel karena mempunyai nilai cronbach's alpha lebih besar dari 0,70.

Hasil Uji Asumsi Klasik. Hasil Uji Normalitas Data. Berikut ini disajikan gambar grafik yang menunjukkan hasil uji normalitas data dengan menggunakan metode normal probability plot.

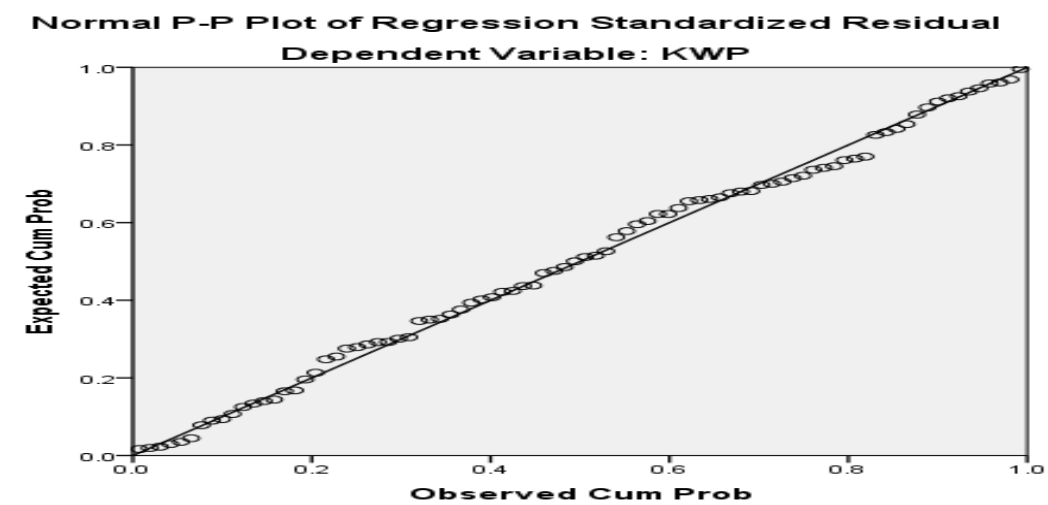

Gambar 2. Uji Normalitas Data Secara Grafik

Sumber: data primer yang diolah

Dari gambar grafik diatas terlihat bahwa normal plot titik-titik menyebar di sekitar garis diagonal, serta penyebarannya mengikuti arah garis diagonal. Dari gambar grafik tersebut maka dapat disimpulkan distribusi data memenuhi asumsi normalitas. 
Hasil Uji Multikolinearitas. Berikut ini disajikan tabel hasil uji probel multikolinieritas dengan menggunakan nilai tolerance dan nilai variance inflation factor (VIF).

Tabel 9. Hasil Uji Multikolinearitas

Coefficients $^{\mathrm{a}}$

\begin{tabular}{lllll}
\hline Model & & \multicolumn{3}{c}{ Collinearity Statistics } \\
\cline { 3 - 5 } \multicolumn{3}{c}{} & (Constant) & \multicolumn{3}{c}{ Tolerance } \\
\hline & KP & .403 & 2.482 \\
& KM & .357 & 2.803 \\
& KK & .383 & 2.608 \\
\hline
\end{tabular}

a. Dependent Variable: KWP

Sumber: data primer yang diolah

Dari tabel di atas dapat diketahui bahwa masing-masing variabel mempunyai nilai tolerance mendekati angka 1 dan nilai variance inflation factor (VIF) dibawah angka 10. Dengan demikian dapat disimpulkan bahwa pada persamaan regresi di penelitian ini tidak terdapat problem multikolinearitas.

Hasil Uji Heteroskedastisitas. Berikut ini disajikan tabel hasil uji problem heteroskedastisitas dengan menggunakan Scatterplot.

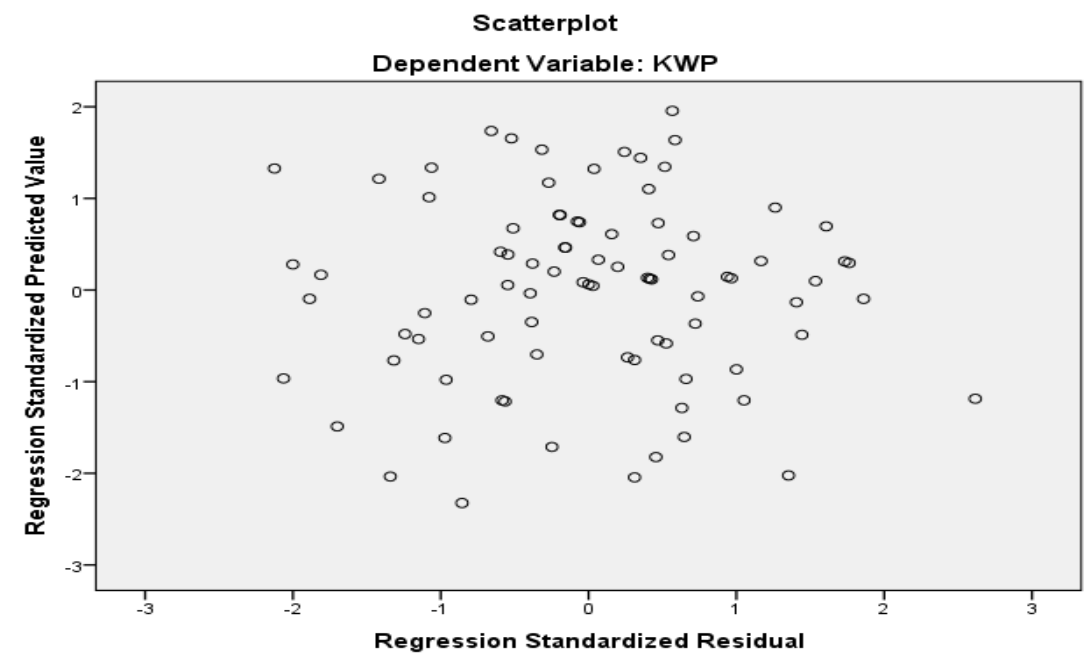

Gambar 3. Hasil Uji Heteroskedastisitas

Sumber: data primer yang diolah

Dari grafik Scatterplot yang ada pada gambar di atas dapat dilihat bahwa titik-titik menyebar secara acak, serta tersebar baik di atas maupun dibawah angka nol pada sumbu Y. Hal ini dapat disimpulkan bahwa tidak terjadi heteroskedastisitas pada model regresi. (Ghozali 2011: 139).

Hasil Uji Analisis Regresi Berganda. Hasil Uji Kecocokan Model. Berikut ini disajikan hasil uji kecocokan model. 
Tabel 10. Hasil Uji Determinasi (Adjusted $R^{2}$ )

Model Summary ${ }^{b}$

\begin{tabular}{|c|c|c|c|c|c|}
\hline Model & $\mathrm{R}$ & R Square & $\begin{array}{c}\text { Adjusted R } \\
\text { Square }\end{array}$ & $\begin{array}{l}\text { Std. Error of } \\
\text { the Estimate }\end{array}$ & $\begin{array}{l}\text { Durbin- } \\
\text { Watson }\end{array}$ \\
\hline 1 & $.863^{\mathrm{a}}$ & .745 & .736 & .23215 & 2.257 \\
\hline
\end{tabular}

a. Predictors: (Constant), KK, KP, KM

b. Dependent Variable: KWP

Sumber: data primer yang diolah

Berdasarkan tabel model summary ${ }^{b}$ di atas diperoleh bahwa nilai koefisien korelasi berganda $(R)$ sebesar 0,863. Ini menunjukkan bahwa variabel kemudahan penggunaan, kemanfaatan, keamanan dan kerahasiaan terhadap kepuasan wajib pajak mempunyai hubungan yang sangat kuat (86,3\%). Hasil pada tabel di atas juga menunjukkan bahwa nilai Adjusted $R$ Square sebesar 0,736. Hal ini berarti bahwa kepuasan Wajib Pajak bisa dijelaskan oleh variasi variabel independen (kemudahan penggunaan, kemanfaatan, keamanan dan kerahasiaan) sebesar 73,6\%. Sedangkan sisanya $(100 \%-73,6 \%=26,4 \%)$ dijelaskan oleh variabel lain yang tidak diuji dalam penelitian ini, antara lain misalnya variabel: kualitas pelayanan (Rusydi dan Fathoni, 2011), ekspektasi kinerja, ekspektasi usaha (Sugihanti, 2011), pengalaman (Pratiwi, 2012) .

Hasil Uji Hipotesis. Berikut ini disajikan hasil uji yang dilakukan secara parsial.

Tabel 11. Hasil Uji t (Parsial)

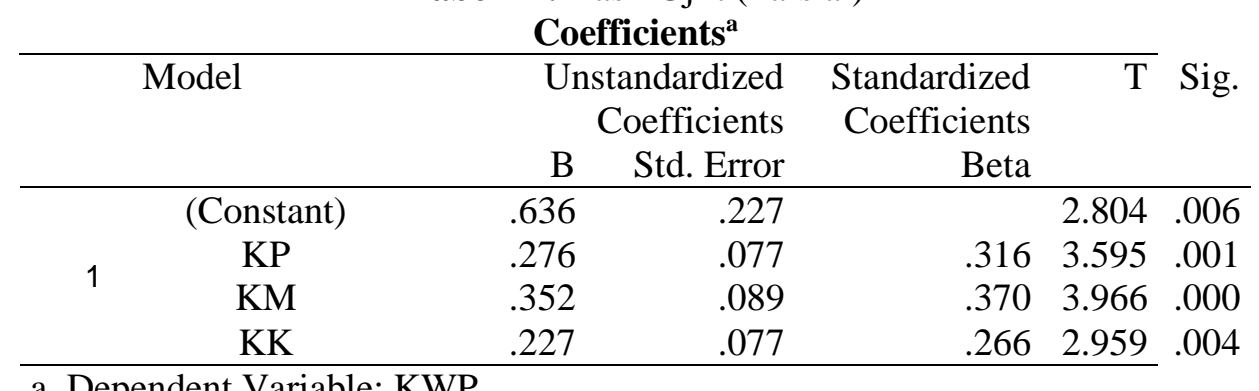

a. Dependent Variable: KWP

Sumber: data primer yang diolah

Hasil pengujian yang disajikan pada tabel di atas dapat digunakan untuk menjawab hipotesis 1, hipotesis 2, dan hipotesis 3. Berdasarkan tabel tersebut dapat diketahui bahwa hasil uji hipotesis 1 menunjukkan nilai signifikansi untuk variabel Kemudahan Penggunaan sebesar 0,001. Sehubungan nilai ini lebih kecil dari 0,05, maka dapat disimpulkan bahwa hipotesis pertama $\left(\mathrm{H}_{\mathrm{a}}\right)$ yang menyatakan: "persepsi kemudahan penggunaan e-Filing berpengaruh secara positif dan signifikan terhadap kepuasan Wajib Pajak" dapat didukung. Untuk hipotesis $2\left(\mathrm{H}_{\mathrm{a} 2}\right)$ dapat diketahui bahwa nilai signifikansi untuk variabel Kemanfaatan sebesar 0,000. Sehubungan nilai ini lebih kecil dari 0,05, maka dapat disimpulkan bahwa hipotesis pertama $\left(\mathrm{H}_{\mathrm{a} 2}\right)$ yang menyatakan: "Persepsi kemanfaatan penggunaan e-Filing berpengaruh secara positif dan signifikan terhadap kepuasan Wajib Pajak” dapat didukung. Untuk hipotesis $3\left(\mathrm{H}_{\mathrm{a} 3}\right)$ dapat diketahui bahwa nilai signifikansi untuk variabel Keamanan dan Kerahasiaan sebesar 0,004. Sehubungan nilai ini lebih kecil dari 0,05, maka dapat disimpulkan bahwa hipotesis pertama $\left(\mathrm{H}_{\mathrm{a} 3}\right)$ yang 
menyatakan: "Keamanan dan kerahasiaan penggunaan e-Filing berpengaruh secara positif dan signifikan terhadap kepuasan Wajib Pajak” dapat didukung.

Pembahasan. Dengan didukungnya hipotesis pertama yang menyatakan bahwa kemudahan penggunaan fasilitasn E-filing berpengaruh positif dan signifikan terhadap kepuasan Wajib Pajak, maka dapat diterjemahkan bahwa semakin mudah fasilitas e-filing digunakan maka akan semakin memuaskan Wajib Pajak. Hasil penelitian ini konsisten dengan penelitian yang dilakukan oleh Noviandini (2012). Mengacu pada hasil temuan ini, diharapkan dapat menjadi catatan penting bagi Kantor Pelayanan Pajak dalam upaya meningkatkan kemudahan dalam penggunaan e-Filing, sehingga tingkat kepuasan Wajib Pajak dalam menggunakan $e$-Filing akan semakin meningkat.

Dengan didukungnya hipotesis kedua yang menyatakan bahwa kemanfaatan berpengaruh secara positif dan signifikan terhadap kepuasan Wajib Pajak, maka dapat diartikan bahwa semakin tinggi kemanfaatan fasilitas e-Filing maka akan semakin meningkat kepuasan Wajib Pajak. Hasil penelitian ini konsisten dengan penelitian yang dilakukan oleh Pratiwi (2012) dalam penggunaan Mobile Banking. Selain itu, hasil penelitian ini juga konsisten dengan hasil penelitian yang dilakukan oleh Irmadhani dan Nugroho (2011) dalam penggunaan Online banking.

Temuan yang membuktikan bahwa semakin besar kemanfaatan dalam penggunaan $e$-Filing maka dapat berdampak dalam memuaskan Wajib Pajak dalam menggunakan $e$ Filing. Dengan demikian, Kantor Pelayanan Pajak diharapkan dapat mendorong dalam meningkatkan kemanfaatan yang lebih banyak dalam penggunaan fasilitas e-Filing sehingga diharapkan dapat meningkatkan kepuasan bagi Wajib Pajak dalam menggunakannya.

Dengan didukungnya hipotesis ketiga yang menyatakan bahwa keamanan dan kerahasiaan berpengaruh positif dan signifikan terhadap kepuasan Wajib Pajak, hal ini menunjukkan bahwa semakin kuat tingkat keamanan dan kerahasiaan maka akan semakin tinggi tingkat kepuasan Wajib Pajak. Hasil penelitian konsisten dengan penelitian yang dilakukan oleh Turinawe dan Mwesigwa (2013) dalam penggunaan Internet Banking. Temuan ini diharapkan dapat mendorong Kantor Pelayanan Pajak dalam meningkatkan kemanan dan menjaga kerahasiaan data Wajib Pajak dari risiko hilangnya maupun kerusakan data.

Hasil penelitian ini dapat berimplikasi terhadap Kantor Pelayana Pajak maupun Direktorat Jenderal Pajak dalam membuat kebijakan pemberlakuan e-Filing agar memperhatikan dan meningkatkan aspek kemudahan, aspek kemanfaatan, dan aspek keamanan serta kerahasiaan fasilitas $e$-Filing dengan tidak menyulitkan dalam pelaporan dalam penyampaian SPT sehingga dapat meningkatkan kepuasan Wajib Pajak. Kepuasan Wajib Pajak ini merupakan aspek penting yang dapat dijadikan sebagai salah satu tolok ukur keberhasilan Kantor Pelayanan Pajak dalam melakukan tugasnya. Dengan meningkatnya kepuasan wajib pajak yang salah satunya disebabkan oleh kemudahan penggunaan fasilitias e-filing, aspek kemanfaatannya terjamin, dan keamanan dan kerahasiaan data dapat terjaga, diharapkan dapat meningkatkan keinginan wajib pajak dalam memenuhi kewajiban perpajakannya, sehingga peningkatan jumlah pendapatan negara dari sektor pajak ini diharapkan dapat meningkat. 


\section{PENUTUP}

Kesimpulan. Berdasarkan hasil pengujian dan analisis terhadap dapat maka dapat dibuat beberapa kesimpulan sebagai berikut: (1) Aspek kemudahan dalam penggunaan fasililitas e-Filing berpengaruh secara positif dan signifikan terhadap kepuasan Wajib Pajak, (2) Aspek kemanfaatan atas penggunaan fasilitas e-Filing berpengaruh positif dan signifikan terhadap kepuasan Wajib Pajak, dan (3) Aspek keamanan dan kerahasiaan fasilitas $e$ Filing berpengaruh secara positif dan signifikan terhadap kepuasan Wajib Pajak.

Saran. Bagi penelitian berikutnya, berikut ini beberapa saran yang diharapkan dapat bermanfaat bagi penelitian selanjutnya: (1) Perlu dipertimbangkan untuk memperluas area penelitian sehingga kemampuan generalisasinya lebih tinggi; (2) Perlu dipertimbangkan untuk menambah jenis Wajib Pajak selain jenis Wajib Pajak Badan agar bisa dibedakan persamaan/perbedaan persepsi diantara dua Wajib Pajak yang ada; (3) Perlu dipertimbangkan untuk menggunakan metode pemilihan sampel lainnya selain metode convenience sampling agar distribusi responden lebih merepresentasikan persepsi populasi penelitian, misalnya dengan menggunakan metode stratified random sampling atau simple random sampling; (4) Perlu dipertimbangkan untuk menambah variabel penelitian lain yang diduga dapat berpengaruh terhadap Kepuasan Wajib Pajak, misalnya variabel kecepatan akses $e$-filing, kecepatan respon $e$-filing, maupun variabel penelitian lainnya.

\section{DAFTAR RUJUKAN}

Davis, F.D., (1989). Perceived Usefulness, Perceived Ease of Use, and User Acceptance of Information Technology. MIS Quarterly. Vol. 13, (5): pp 319-339, (1989).

Devano, Sony dan Kurnia, Siti. (2006). Perpajakan: Konsep, Teori, dan Isu, Edisi 1, Kencana, Jakarta.

Devi, Ni luh Nyoman dan Wayan Suartana. (2014). Analisis Technologh Acceptance Model terhadap Penggunaan Sitem Informasi di Nusa Dua Beach Hotel \& spa”, Ejurnal akuntansi Universitas Udayana 6.1: 167-184.

Ghozali, Imam. (2011). Aplikasi Analisis Multivariate Dengan Program SPSS, Badan Penerbit Universitas Diponegoro, Semarang.

Indriantoro, dan Supomo. (2004). Metodologi Penelitian Bisnis untuk Akuntansi dan Manajemen. BPFE Yogyakarta.

Irmadhani dan Nugroho. (2011). Pengaruh Persepsi Kebermanfaatan, Persepsi Kemudahan Penggunaan dan Computer Self Efficacy terhadap Penggunaan Online Banking Pada Mahasiswa S1 Fakultas Ekonomi Universitas Negri Yogyakarta. Jurnal Akuntansi dan Bisnis Vol.1 (2) Desember 2011:1 - 20.

Kotler, Philip. (2000). Manajemen Pemasaran, Pabelan Surakarta, Jakarta.

Keputusan Direktur Jenderal Pajak Nomor KEP-88/PJ/2004 tanggal 14 Mei 2004 (BN No.7069 hal. 4B) tentang penyampaian Surat Pemberitahuan Secara Elektronik.

Keputusan Direktur Jenderal Pajak Nomor KEP-05/PJ/2005 tanggal 12 Januari 2005. Tentang Tata Cara Penyampaian Surat Pemberitahuan Secara Elektronik Melalui Perusahaan Jasa Aplikasi.

Keputusan Direktur Jenderal Pajak Nomor Kep-38/PJ/2008 Tentang Surat Pemberitahuan Tahunan Pajak Penghasilan Wajib Pajak Badan, Surat Pemberitahuan Tahunan Pajak 
Penghasilan Wajib Pajak Orang Pribadi dan Surat Pemberitahuan Tahunan Pajak Penghasilan Pasal 21 Tahun 2007.

Keputusan Direktur Jenderal Pajak Nomor Kep-47/PJ/2008 Tentang Tata Cara Penyampaian Surat Pemberitahuan dan Penyampaian Pemberitahuan Perpanjangan Surat Pemberitahuan Tahunan Secara Elektronik (e-Filing) Melalui Perusahaan Jasa Aplikasi (ASP)

Laihad, Risal C.Y., (2013). Pengaruh Perilaku Wajib Pajak terhadap Penggunaan e-Filing Wajib Pajak di Kota Manado. Jurnal EMBA Vol. 1 (3). September.

Noviandini, Nurul Citra. (2012). Pengaruh Persepsi Kebermanfaatan, Kemudahan Penggunaan, Kepuasan Wajib Pajak terhadap Penggunaan E-Filing Bagi Wajib Pajak di Yogyakarta. Jurnal Nominal / Volume I Nomor I / Tahun 2012.

Pratiwi, Devvy Pisheila. (2012). Pengaruh Persepsi Manfaat, Persepsi Kemudahan Penggunaan dan Pengalaman terhadap Perilaku Penggunaan Mobile Banking Dengan Mediasi Niat Pengguna Mobile Banking Nasabah Bank BCA Surabaya. Jurnal Akuntansi Vol.2 (2), 2012: 1-18.

Raymond Mc Leod dan Schell George P., (2009). Sistem Informasi Manajemen, Edisi 10, Salemba Empat.

Rusydi, M.Khoiru dan Fathoni. (2011). Pengaruh Kualitas Pelayanan terhadap Kepuasan Wajib Pajak Kendaraan Bermotor di Kota Batu. Jurnal Aplikasi Manajemen, Volume 9 (3), Mei.

Sugihanti, Wina Titis. (2011). Analisis Faktor-Faktor yang Mempengaruhi Minat Perilaku Wajib Pajak untuk Menggunakan e-Filing. Diponegoro Journal of Accounting. Volume 1, (3), Tahun 2011, Halaman 1.

Turinawe, Eng. Dickinson dan Mwesigwa, Rogers. (2013). Information on Internet Banking, security and Privacy, Quality of Internet connection, Perceived Value, and Internet Banking Acceptance in Uganda. International Journal of Economic and Management Science, Vol. 2 (11). 